E Q U I L I B R I U M

VOLume 6 IsSue 4, 2011

IS S N $1689-765 \mathrm{X}$

Stanisław Rudolf

University of Lodz, Poland

\title{
The Impact of Economic Crises on Changes \\ in Corporate Governance
}

\section{JEL Classification Codes: $A$}

Keywords: corporate governance, economic crisis, supervisory board, convergence

\begin{abstract}
Over the last 10-15 years significant changes took place in principal systems of corporate governance i.e. in the Anglo-Saxon and German systems. These changes were of similar or the same character. This was an effect of economic crises, mainly crises of 1997-1998 and 2007-2009. The crises have influenced the changes either directly through amendments in the so-called hard law of national systems of supervision or indirectly through recommendations on corporate governance issued by international institutions and organizations. The OECD and the European Commission played the most important part in this respect. These organizations had a big impact on the formation and shape of the so-called codes of good practice, whose principles are generally implemented by companies, mainly listed companies. The principles happen to be of the so-called soft law character and after some encouraging experience with their use take on the form of legislation.
\end{abstract}

\section{Introduction}

Starting from the 1970s, major changes took place in the existing systems of corporate governance. However, the biggest change took place over the last 10-15 years. It was then that more attention was paid to the functioning of corporate governance. Indeed, it was then realized that the governance may become an important factor of economic growth and increased competitiveness of economy. The appropriate corporate governance allows better use of companies' capital and increases the confidence of domestic and foreign investors. Corporate governance influences the location of foreign direct investment. Governance may also make the company not to be guided solely by self-interest, but to take into 
account in its activities the interests of the state, region or community. Studies show that investors prefer to buy shares of companies with high-quality corporate governance (Jeżak 2010, pp. 12-14).

It was the growing concern for the quality of governance that it is undergoing evolutionary process. On the one hand, such process is enforced by increasing competition, and on the other hand, by changing environment in which companies operate. Increased competition, both at home and on international markets, places high demands on performance of companies, the rationality of their actions, but also their transparency, ability to cope with crisis situations, etc. Corporate governance, which we may understand as "a set of integrated mechanisms; regulatory (formal and legal), and market and internal mechanisms, through which the company management makes decisions and choices that are in line with the objectives of shareholders and other stakeholders related to the activity of the company" (Urbanek 2005, p. 7), may play an important role in meeting these demands, but only if it is adapted to existing conditions, if it supports the company in achieving its objectives. Because the conditions change, the system of corporate governance must also be changed.

A careful analysis of changes in corporate governance leads to the conclusion that the changes occur in general, in a continuous, evolutionary manner. Such changes are taking place in different systems of corporate governance and concern its different areas. At the same time we can see changes of essential and deep nature, consequences of serious economic crises. It is a widely accepted fact that one of the causes of such crises is inadequate corporate governance. The changes are aimed at improving the supervision and thus to prevent future crises. Of course, not every crisis entails such changes. They are of different scope, different depth and hence of different significance for the economy. According to J. Stiglitz, 124 such crises took place between 1970 and 2007 (Stiglitz 2010, p. XVIII). Further, we will demonstrate the impact of the two biggest crises of recent years, i.e. the 1997-1998 crisis and the 2007-2009 crisis on the corporate governance.

The reform of corporate governance systems is based on the so-called soft law and hard law. The soft law is a recommendation of a voluntary character. Therefore, companies may impose or not the recommended rules, they may decide when to apply recommendations, and decide the pace of their implementation, etc. The method of reforming the supervisory systems by means of soft law gives companies considerable flexibility. For some time, the so-called codes of good practice ${ }^{1}$ have become the major means of conveying this law. The recommendations contained therein are general in character and are so worded, so that they could be implemented by a large number of companies. The past experi-

${ }^{1}$ Further considerations on the codes of good practice can be found in: Furtek, Jurcewicz 2006, pp. 28-30. 
ence, including the Polish one, shows that the soft law, although it is not mandatory, may be effective, especially in the long run (Nartowski 2007, pp. 3-16).

Experience also shows that principles of the soft law may prove insufficient to prevent more serious difficulties and crises. It is not always that the codes' recommendations are implemented by companies; sometimes the companies are strongly reluctant to implement the recommendations. This particularly concerns the unpopular solutions that require deeper changes or much effort. Then, the hard law, of mandatory character, should be applied. Changes in the law are mostly enforced by the crisis, or other important economic events (such as the collapse of the well-known corporations as Enron, WorldCom or Parmalat). It also happens that some of the principles of the soft law, after favorable experience with their application, are incorporated into the hard law.

The purpose of the study is to determine the influence of the two biggest economic crises in recent years, namely the crisis of 1997-1998 and the crisis of 2007-2009 on changes in corporate governance. Crises may affect such changes both directly and indirectly. This must be understood that changes taking place in individual countries might have been the direct result of crisis events as well as of the implementation of the recommendations of international organizations or institutions, formulated under the influence of crises. The paper will show the changes in countries with one-tier board system, typical of Anglo-Saxon countries and in countries with two-tier board system, with particular emphasis on the so-called German system, in use in Poland.

\section{The impact of the 1997-1998 crisis on changes in corporate governance}

This crisis started in Thailand in 1997 when the government closed 56 out of 58 financial institutions due to the collapse of the local currency (Baht). Thai banks borrowed dollars from the West and granted loans for construction of hotels, office buildings, factories, etc. The government guaranteed to exchange baht at a fixed rate, but this proved impossible and the Thai baht was depreciated by $30 \%$. This entire financial system has collapsed since the borrowers had to pay $30 \%$ more than planned. The crisis in Thailand caused the flight of capital from all emerging South Asian countries (the collapse of the Korean, Malaysian, and Indonesian currency). The effects were felt around the world.

Southeast Asia fuelled the global economic growth consuming huge amounts of raw materials. The recession in these countries caused prices of copper, aluminum, and oil to fall. This resulted in the crisis moving to Russia, which was selling mainly oil and gas in the West. The situation in Russia was becoming increasingly critical, so Russia raised the interest rates on their bonds from 20 to 50 or even $70 \%$. Hedge funds were still buying them, hoping that if neces- 
sary, the IMF would help Russia. But the IMF preferred to save Thailand and Korea, which led in 1998 to the crisis in Russia. The ruble was devaluated and the Russian government suspended payments on treasury bills. Hedge funds and banks investing in Russia have suffered huge losses (Friedman 2001, pp. 5-10).

This had further implications for the global financial system, although the Russian economic potential was rather small (smaller than the potential of the Netherlands). Having incurred huge losses in Russia, the speculative capital was looking for cash, so began to sell stock in stable countries such as Brazil. This country, without any rational basis has found itself in trouble, a mass retreat of foreign capital began (raising the bond interest to $40 \%$ did not help). Speculative capital moved to the U.S. buying U.S. Treasury securities. Demand for the papers raised their price, which resulted in the reduction of their interest rate. The sharp decline in profitability of these investments has forced speculative capital to look for other investments.

The mechanism described above, known as the Asian crisis, is typical of contemporary crises. It usually starts in one country and then spreads to the entire region and beyond to the whole world. The processes of globalization caused that the world has become one big self-regulating system. The crises appear from time to time and are difficult to control because of the free movement of capital. Not coincidentally, the crisis appears first in the sphere of finance and then engulfs the whole economy.

The crisis, because of its unprecedented size, brought an extensive discussion about its causes, as well as on the possibilities of its prevention. The weakness of corporate governance, mainly in financial institutions, but not only, was found as one of the most important causes. The criticism of the existing corporate governance has resulted in suggestions to reform the system. The Organization for Economic Cooperation and Development (OECD) played the special role in reform by preparing corporate governance rules and reports on its operation. An important role was played by the recommendations issued by the European Commission and other EU bodies.

The OECD interest in corporate governance issues has been growing for a long time, mainly under the influence of the British experience (Cadbury Report (1992), Greenbury Report (1995), and Hampel Report (1997)). The breakthrough came, however, with the said crisis that resulted in the publication of the 1999 OECD Principles of Corporate Governance (Principles... 1999). They principles were treated as guidelines for member countries of the organization for the development of national legislations or other documents relating to corporate governance. The principles are of open character and allow companies to continuously modify them, customize solutions relating to corporate governance to changing conditions. The OECD Principles are the soft law instruments (guidelines) to be used voluntarily by companies. They should be regarded as 
a sort of international standards to which individual countries may refer their solutions (Jerzemowska 2010, pp. 38-39).

Even though OECD recognizes that there is no one best model of good governance, but also indicates some universal principles that should be used in each of these models, for example, equitable treatment of all shareholders and partners, regardless of ownership or their place of residence and ensuring their basic rights arising from the possession of property. OECD points also to disclosure and transparency of information on economic performance, ownership structure, methods of control and governance, etc. as well as recommendations to ensure the reliability of accounting and financial reporting. It is difficult to overestimate the role of the guidelines for the development of national or company codes of good practice. In Europe, for example, dozens of such codes were prepared on the basis of the Principles. The Principles were also the inspiration for the Polish codes of good practice.

Another set of the OECD principles of corporate governance, an amendment of the 1999 Principles, was published in 2004 (The OECD... 2004). It was worked out not only by the representatives of the OECD member countries, but also by the experts of the World Bank, International Monetary Fund, the Basel Committee on Banking Supervision, and many others. The Principles, like their previous edition, were formulated in very general terms, because they addressed countries with different systems of corporate governance. Especially noteworthy were the recommendations concerning the independent board members, in the context of an objective assessment of company's financial situation. The growing number of independent members of the board increases the chances of an appropriate assessment of the Board's operation and makes it possible to take on this basis responsible and effective actions. The document contains some general suggestions about such independence criteria (a lack of close economic or personal relationship with the members of top management, major shareholders, etc.). Based on these criteria the board determines whether they are considered as independent by the board.

Changes in supervision are also of interest to the EU. In result of the crisis and many scams, fraud or other corporate crimes related to the so-called "Creative accounting" between 2000 and 2002, the European Commission appointed an expert group to assess the implementation of the principles of corporate governance in the EU. The group prepared the so-called "Winter group" report published in November 2002 (Winter 2002). The authors generally critically assessed the implementation of the OECD Principles, pointing to the differences between particular countries. The authors are in favor of the increased participation of the socalled independent directors on the board. They consider the increased number of independent directors as a possibility of improving the performance of the board. Particularly, they stress the role of audit committees and remuneration committees, because the committees have a significant impact on the performance of the board. 
Important inspirations for a change in national systems of corporate governance were also recommendations of the European Commission and other EU bodies. One of the first was the European Commission Recommendation of 14 December 2004, primarily focused on the transparency of the remuneration policy of members of the management board. The recommendation stresses the role of independent members, who should exercise control over the transparency and integrity of company management. These members should represent not only the interests of shareholders but also reconcile the interests of other stakeholders. There are also recommendations concerning the appointment of such board committees as audit, nomination, and remuneration committees. The recommendation requires the board to disclose company remuneration policy, as well as salaries of the board members. It is also recommended that the salary issue be mandatory subject of discussion at the annual general meeting (Zalecenie... 2004).

Another European Commission Recommendation of 15 February 2005 (Zalecenie... 2005) concerns the appointment of remuneration committees. The committees should include only the non-executive directors (one-tier system). In addition, a majority of their members should be independent. The tasks of the committee should include formulating of remuneration rules for the board members and presentation of these rules to the council, monitoring of chief executive officers' remuneration, preparation of proposals for incentive schemes or their changes, etc. The recommendation also recommends that the number of the independent board members should be increased. The Annex II of this document contains the proposals of independence criteria.

Turning to the presentation of changes in corporate governance in selected countries it must be noted that the biggest changes took place during this period in the U.S. The crisis, as well as the mentioned corruption scandals that have occurred in the early 20th century meant that the main attention was paid to the issues of audit. Many reports and recommendations have been devoted to these issues. The 1999 Blue Ribbon Committee report deserves special attention, with important new recommendations aimed at strengthening the independence of these committees and increasing their efficiency (Blue Ribbon 1999). The recommendations were widely used by The Polish Securities and Exchange Commission and associations of accountants in Poland.

The 2002 (An Act... 2002) Sarbanes-Oxley Act (SOX) was one of the milestones in the reform of the U.S. corporate governance system. The Act may be a good example of the conversion of the soft law into the hard law because it contains many of the recommendations contained in the Blue Ribbon Committee report, as well as in the codes of good practice. In some cases, the Act goes even further than these recommendations. Because the Act has not only introduced the regulations required for the appointment of the audit committee, but has also provided the committee with wide powers that require an employer to provide 
the relevant information to the committee and to secure funding for its activities (appointment of consultants, research, etc.).

Under the Act, the committees should play a leading role in the selection of auditors. The committees should closely cooperate with the auditors. The Act has clearly increased the requirements for internal controls and imposed more responsibility on the management for the operations of the company. Above all, the Act has increased the independence of regulatory and supervisory bodies, which has always aroused considerable concern in the one-tier system. It is worth noting that the Act has not only increased the independence of members of board of directors, but has also imposed the greater responsibility for the operation of the company on them. Worth noting is the regulation requiring committees to formulate procedures for reporting irregularities or fraud. The Act requires company analysts to report the irregularities to the committees.

The OECD Principles have also changed the American codes of good practice. The Principles recommended increasing the number of the non-executive directors in the board, and among them, the directors meeting the independence criteria. The Code of 2003, for example, recommends that the boards of companies listed on the NYSE should be composed of a majority of independent board members. The code defined in some detail requirements for independence. No director who is a former employee of the listed company could be "independent" until five years after the employment has ended. The code required from directors lack of personal ties to the management, lack of business ties, both within the company itself and beyond. The latter aspect has been extensively developed (Corporate Governance... 2003). The codes substantially changed the structure of the board. The non-executive directors in the 1980s accounted for approximately $20 \%$ of board members, today their share has increased to about $80 \%$ (Jeżak 2010 pp. 166-168).

Similar changes took place in the British system of corporate governance. They mainly involved successive editions of the codes of good practice. It is worth noting that the first code of good practice was developed in 1992 in Great Britain (The Cadbury... 1992). Subsequent editions of these codes, especially after the publication of OECD Principles, focused mainly on increasing the number of non-executive board members. The codes also recommended having people independent from the company on the board. The codes required these persons not to have any economic or family ties with the management of the company. The board was to assess the evaluation criteria of independence.

This crisis has also exposed the weaknesses of corporate governance in Germany. Hostile takeovers and corruption scandals forced the government to appoint the committee to prepare proposals for the reform in the field of corporate governance. In July 2001 the committee, named after its chairman Baums Commission, presented a catalogue of 150 detailed recommendations for amendments to the Commercial Code and the Code of Good Practice (Baums Commission... 
2001). On this basis, the Code of Corporate Governance (German Corporate..., 2002) was prepared in February 2002. It differs quite substantially from similar codes in other countries, mainly due to its structure. The first part of the code includes regulations on German corporate governance system. The second part contains recommendations to be implemented on a voluntary basis (comply or explain). The third part includes the proposals without the requirement to comply or explain why they have not been implemented.

Recommendations for independent board members were in the second part of the code and were of a very general nature, for example the "appropriate" number of independent board members has been mentioned. It should be noted, however, that importance of the number of such members for the independence of the supervisory board is smaller than that of the board of directors. In the German system all members of the supervisory board are non-executive members recruited from the outside of the company's management. Hence, the supervisory board is in principle more independent than the board of directors.

In countries with a German system of supervisory board, the committees were established much later than in the Anglo-Saxon countries, as late as at the end of the 1990s (the Netherlands, Portugal). On a broader scale the committees began to be developed in the early 21 st century, with the spread of codes of good practice. The codes of good practice recommend that the committee should be chaired by an independent member, with adequate expertise in accounting and finance.

Recommendations for the presence of independent members on the board are also found in subsequent editions of Polish codes of good practice. However, if the EU countries more or less tend to increase the number of independent members on the board, the trend in Poland is reversed. The most ambitious in this respect was the first Code of Practice 2002 (Dobre praktyki... 2002), which recommended that independent members should account for at least $50 \%$ of the board members. Such level turned out to be far too high, because the independence criterion was met by only about $20 \%$ of listed companies (Nogalski, Dadaj 2006, p. 351). Despite this, the $50 \%$ share of independent members was retained in the Code of 2005, making an exception for companies with a leading shareholder, with a controlling interest securing over $50 \%$ of voting stock shares.

The recommendations for audit committees have also undergone changes in the successive editions of the Polish codes of good practice. The committees are appointed in order to assist the board in its regulatory and supervisory functions. Recommendation for the appointment of such committees were for the first time included in the Code of 2005 according to which the audit committee should be composed of independent board members. By virtue of the Code criteria of independence only $25 \%$ of companies met this criterion (Campbell, Jerzemowska, Najman 2006, p. 362); hence such committees have been rarely appointed. It is hardly surprising that the next edition of the Code of 2007 relaxed the criteria 
for appointment of audit committees. At least one independent member with adequate expertise in finance and accounting necessary to perform this role should be in the committee. It was also recommended to use the said recommendations of the European Commission of 15 February 2005 concerning the role and activities of such committees.

Recommendations concerning the presence of independent board members can also be found in the codes of practice in the Central and Eastern Europe countries. The research on these codes was conducted by P. M. Przybyłowicz Tamowicz (Przybylowicz, Tamowicz 2008, pp. 241-257) in 2007. The research shows that all countries (12) except for Romania recommended in their codes the presence of independent members on the board. The degree of detail, the scope and criteria of the recommendations varied. Countries such as Estonia, Latvia and Hungary have used the criteria already mentioned in the Recommendations of the European Commission. In countries like the Czech Republic, Lithuania, Slovakia and Ukraine, the criteria were very general, similar to the OECD Principles. The codes of good practice did not specify, however, the number of such members, or defined their scope in a very general way (such as the sufficient number -- as in the OECD principles). However, their participation in the audit, nomination, and remuneration committees was noted. It follows from the reports that the report authors have extensively used the ready-made solutions, without trying to adapt them to existing conditions in the country.

\section{Impact of the 2007-2009 crisis on changes in supervision}

The changes in corporate governance proved to be insufficient, hence another, the deepest crisis in recent decades came. This did not mean that the changes fell short of expectations. To a large extent, the causes of previous crises have been eliminated. The audit committees and similar measures aimed at eliminating or reducing the creative accounting have contributed to this end. The errors in management, incompetence of decision makers in strategic decisions, excessive compensation for CEOs and board members, even when the company made losses, etc. were the reasons for the crisis. Unlike before, such actions although reprehensible, were consistent with the law (Urbanek 2010, p. 1617).

The crisis has brought further recommendations of the said institutions as well as specific projects in individual countries. The OECD report of June 2009 (Corporate Governance... 2009) was an important document, which pointed out the causes of the crisis. In addition to excessive executive remuneration and lack of accountability, particularly in matters of risk management the report indicated inadequate operation of supervisory boards and boards of directors. Although the report recommends increasing the number of independent members on the 
board, but at the same time does not consider this issue as a cure for all problems in the company. Still, the independent members must have adequate expertise and experience necessary to work in the board or its committees. The report recommends making deliberate selection and training of members of the board (Duam 2010).

Particularly noteworthy are also two further European Commission Recommendations of 30 April 2009 (Zalecenia... 2009, No. 384 and 385), prepared during the economic crisis, when the scope and some effects of the crisis were already known. The recommendations were amended in regard to executive remuneration, emphasizing not only its transparency, but also procedures for determining the Ceo's compensation and in particular in regard to its variable components. Generally it was recommended to pay the variable component only if performance criteria were met, with an obligation to return the variable component if it was paid based on unreliable data, and to defer payment of remuneration in questionable situations, etc. The recommendation for appointment of remuneration committees by the board was repeated. Not coincidentally, much attention was paid to remuneration in financial institutions, which were most affected by the crisis. It was recommended to coordinate the remuneration policy with risk management.

One can name many other EU initiatives encouraging member countries to make changes in their corporate governance systems. Quite often the changes concern remuneration policies in companies (Urbanek 2010, pp. 93-94), for example, the European Parliament's Resolution of 7 July 2010 on the remuneration of directors of listed companies and remuneration policies in the sector of financial services. One should also mention the European Commission's draft directive requiring EU countries to create for companies the possibility to choose between a one-tier system and a two-tier system of supervision.

Successive editions of the codes of good practice in the UK included recommendations for further increase of the number of independent board members, and increased requirements for independence. The last edition of the Code (2010), postulates that independent directors should account for at least half of the board members. This also means that the board should consist mostly of nonexecutive directors. The requirements for independence have been increased. Besides the lack of business or family ties, the recommendations added a 5-year break after employment has ended lack of relationship with major shareholders, or a continuous stay on the board for more than 9 years (The UK Corporate... 2010). During nearly 20 years the UK has made a significant step forward in independence of the board. However, the majority of members of the board are executive directors $(60 \%)$.

Both in the U.S. and UK consecutive editions of codes of good practice led to the development of the nomination, remuneration and many others committees. The increased significance of these committees was the consequence of the in- 
creased independence of the board itself, the increased number of non-executive members on the board, and the increased number of independent members on the board. The responsibilities of these members and requirements they should meet have been more and more specifically formulated, etc. One of the important standards developed in the one-tier system was the openness of committee operation. The boards have been therefore obliged to disclose the composition of committees, their presidents, frequency of meetings, etc. In general, their task was to prepare proposals or opinions before the decision was taken by the council. Experience proved the need for board committees and today, it is hard to imagine a board of directors in a large corporation without such committees.

The process of developing activities of the committees is still underway, but the 2007-2009 economic crisis brought some changes in this respect. The difficulties experienced by corporations gave rise to development of the so-called risk committees. Until now, the issues of risk remained generally the responsibility of audit committees. Distinguishing the risk issues and assigning special committees can be considered a step in the right direction. This solution is an attempt to adapt to changing conditions. Studies show that this is only the beginning (Mongiardino, Plath 2010, pp. 116-123).

In a similar vein, another German Corporate Governance Code of 2010 (German Corporate... 2010) was prepared. The code maintained the recommendation for "an adequate" number of independent members of the board. Their number should be adequate to the specifics of the enterprise, employment, size of the board, etc. At the same time the said independence is enforced through such selection requirement for board members that may enhance the independence. It is recommended therefore that the supervisory board members should not have any personal or business relations with management board members or with major competitors, etc. It is also recommended that not more than two former members of the management board shall be members of the supervisory board and members of the management board of a listed company shall not accept more than a total of three supervisory board mandates in other supervisory boards.

Such committees as the nomination committee and remuneration committee have gained popularity in countries with a two-tier system. Remuneration committees are particularly popular, although their scope varies between countries. Most often they are appointed by the supervisory boards of listed companies in countries such as Holland, Ireland and Portugal (over 80\%). The situation in Germany is clearly different with only about $5 \%$ of the companies with remuneration committees. The committees have been rarely appointed in Denmark (30\%) and Finland (40\%) (Ferrarini, Moloney, Ungureanu 2010, pp. 73-118).

The American experience has also influenced the dissemination of audit committees in Poland. The Act of 7 May 2009 on Statutory Auditors... in fact established a legal duty to appoint the independent board member and audit committee in listed companies (Ustawa... 2009). According to the Act, these are the 
supervisory board (or the internal audit committee) that should appoint the audit committee from among their members. The composition of the committee (minimum 3 people) should include at least one independent member, with adequate expertise in finance and accounting. This is yet another example in corporate governance of the soft law being replaced with legal regulations.

It should be noted, however, that the legal obligation to appoint the committees was a result of the Accounting Act and not because of changes in the Code of Commercial Companies (as was the case in Germany). However, the Act has not solved the problem, because it only covers about 400 companies listed on the Warsaw Stock Exchange, hence the amendments to the Code of Commercial Companies will have to be made. For these, however, we must wait ${ }^{2}$. The 2010 edition of the code of good practice takes into account the new legal status for the appointment of audit committees in listed companies. The code repeats recommendations to use the Recommendations of European Commission of February 15, 2005 (Dobre praktyki... 2010).

\section{Conclusions}

The above considerations clearly show the dynamic nature of changes in the functioning of corporate governance. Although such changes take place gradually, there is no doubt that the economic crises affect the extent and depth of these changes. It can also be noted that the bigger the crisis, the deeper the changes. Different countries react differently to these crises. Some of them appoint special committees or teams to evaluate the situation in terms of supervision and prepare recommendations for changes. In such cases, changes can be radical in nature. Other countries use the advice or recommendations on corporate governance formulated by international institutions (OECD, EU). In this case, the changes usually are not deep and are generally within the soft law category.

It follows also from the above considerations that the processes of changes are being implemented within two main supervisory systems, that is the onetier and two-tier systems. It is worth noting that the changes are of the same or similar character, which might mean the convergence of these two systems. It is hardly surprising, since the driving force behind these changes is the changing environment in which the companies operate. The ongoing processes of globalization have made the conditions in all countries similar or comparable, whatever the system of supervision. The international institutions have also, to a certain extent, affected the said convergence by issuing the same recommendations for both of these systems.

${ }^{2}$ Further considerations on the tasks of audit committee members can be found in: Gad 2010, pp.123-133. 
The analysis of the impact of crises on changes in corporate governance may suggest that the supervision is the main cause of the crisis. It is difficult to accept such an argument, although it is true that supervision is an important regulator of economic processes. Good supervision can prevent crises, may indicate emerging risks and help take appropriate action. The recent crisis highlighted the need for regulation of financial systems and the need to strengthen supervision. This has been reflected in the development of risk committees. At the same time there emerge postulates for more active attitude of shareholders, including institutional shareholders. There is a strong emphasis on the need for expertise of board members too, etc.

\section{Literature}

An Act to protect, investors by Improving the Accuracy and Reliability of Corporate Disclosure Made Pursuant to the Securities Law, and for Other Purposes, (2002), US Congress, H. R. 3763.

Baums Commission Report (2001), London.

Blue Ribbon Committee on Improving the Effectiveness of Corporate Audit Committee, Report and Recommendations (1999), NYSE, February.

Campbell K., Jerzemowska M., Najman K. (2006), Wstepna analiza przestrzegania zasad nadzoru korporacyjnego przez spółki notowane na GPW w Warszawie w 2005 roku, [in:] Tendencje zmian w nadzorze korporacyjnym, S. Rudolf (ed.), Wydawnictwo Uniwersytetu Łódzkiego, Łódź.

Corporate Governance and Financial Crisis (2009), OECD.

Corporate Governance Code and Principles, Final NYSE Corporate Governance Role (2003), USA.

Dobre praktyki spółek notowanych na GPW 2010 (2010), Warsaw.

Dobre praktyki w spótkach publicznych 2002 (2002), Warsaw.

Duam J. H., (2010) Spencer Stuard Board Index: How Boards are Changing, „Business Week on Line", 17.03.

Ferrarini G., N. Moloney, M-C. Ungureanu, (2010), Executive Remuneration in Crisis: A Critical Assessment of Reforms in Europe, „Journal of Corporate Law Studies”, No 1.

Friedman T. L. (2001), Lexus i drzewo oliwne, Dom Wydawniczy Rebis, Poznań.

Furtek M., W. Jurcewicz (2006), Corporate governance - lad korporacyjny w spółkach akcyjnych, „Przegląd Prawa Handlowego”, nr 6.

Gad J. (2010), Działalność komitetu audytu a wiarygodność sprawozdań finansowych w obliczu kryzysu, [in:] Nadzór korporacyjny w warunkach kryzysu gospodarczego, P. Urbanek (ed.), Wydawnictwo Uniwersytetu Łódzkiego, Łódź.

German Corporate Governance Code (2002), Berlin.

German Corporate Governance Code (2010), The Government Commission on the German Corporate Governance Code, 26 May.

Jerzemowska M. (2010), Zasady nadzoru korporacyjnego OECD w świetle globalnego kryzysu finansowego, [in:] Nadzór korporacyjny w warunkach kryzysu gospodarczego, P. Urbanek (ed.), Wydawnictwo Uniwersytetu Łódzkiego, Łódź. 
Jeżak J. (2010), Ład korporacyjny. Doświadczenia światowe oraz kierunki rozwoju, Wydawnictwo C. H. Beck, Warsaw.

Mongiardino A., Plath C. (2010), Risk Governance at Large Banks: Have Any Lesson Been Learned?, "Journal of Risk Management in Financial Institutions", vol. 3, No 2.

Nartowski A. (2007), Nie dajmy szansy regulatorowi - stosujmy dobre praktyki, „Przegląd Corporate Governance" nr 3 (11).

Nogalski B., Dadaj R. (2006), Kodeksy dobrych praktyk jako narzędzie budowania zaufania na rynku kapitałowym, [in:] Tendencje zmian w nadzorze korporacyjnym, S. Rudolf (ed.), Wydawnictwo Uniwersytetu Łódzkiego, Łódź.

Przybyłowicz M., Tamowicz P. (2008), Instytucja niezależnego członka rady nadzorczej i jej ksztaltowanie się $w$ krajach Europy Środkowo-Wschodniej, [in:] Rola nadzoru korporacyjnego w kreowaniu wartości przedsiębiorstwa, S. Rudolf (ed.), Wydawnictwo Uniwersytetu Łódzkiego, Łódź.

Stiglitz J. E. (2010), Freefall. Jazda bez trzymanki, Polskie Towarzystwo Ekonomiczne, Warsaw.

The Cadbury Code: The Financial Aspects of Corporate Governance (1992), UK.

The OECD Principles of Corporate Governance (2004), OECD.

The UK Corporate Governance Code (2010), Financial Reporting Council, UK, June.

Urbanek P. (2005), Nadzór korporacyjny a wynagrodzenia menedżerów, Wydawnictwo Uniwersytetu Łódzkiego, Łódź.

Urbanek P. (2010), Kryzys finansowy a polityka wynagradzania menedżerów, [in:] Nadzór korporacyjny $w$ warunkach kryzysu gospodarczego, P. Urbanek (ed.), Wydawnictwo Uniwersytetu Łódzkiego, Łódź.

Ustawa z dnia 22 maja 2009 r. o biegłych rewidentach i ich samorządzie, podmiotach uprawnionych do badania sprawozdań finansowych oraz nadzorze publicznym (2009), (Dz.U. nr 77, poz. 649).

Winter J. (ed.) (2002), Report of the High Level Group of Company Law Experts on a Modern Regulatory Framework for Company Law in Europe, Brussels, November 4.

Zalecenie Komisji z dnia 14 grudnia 2004 w sprawie wspierania odpowiedniego systemu wynagrodzeń dyrektorów spółek notowanych na giełdzie, 2004/913/WE (Dz.U. U.E. L 388/55).

Zalecenie Komisji z dnia 15 lutego 2005 r. dotyczące roli dyrektorów niewykonawczych lub będących członkami rady nadzorczej spółek giełdowych i komisji rady (nadzorczej), 2005/162/U.E. (Dz.U. U.E. L.52/51) Załącznik II.

Zalecenie Komisji z dnia 30 kwietnia 2009 r. w sprawie polityki wynagrodzeń w sektorze usług finansowych, 2009/384/WE (Dz. U. UE L 120/22).

Zalecenie Komisji z dnia 30 kwietnia 2009 r. uzupełniające zalecenia 2004/913/WE i 2005/162/WE w sprawie systemów wynagrodzeń dyrektorów spółek notowanych na rynku regulowanym, 2009/385/WE (Dz.U UE L. 120/28).

Zasady nadzoru korporacyjnego (1999), Ministerstwo Skarbu Państwa. 